\title{
THE EFFECT OF INTRADIALYSIS STRETCHING EXERCISE ON THE SCALE OF RESTLESS LEG SYNDROME
}

\author{
Ahyar Nur $^{1)}$, Kadek Ayu Erika ${ }^{2)}$, Andi Wardihan Sinrang ${ }^{3)}$ \\ ${ }^{1}$ Program Studi Magister Ilmu Keperawatan, Fakultas Keperawatan, Universitas Hasanuddin \\ Email : ahyarnur.ns@gmail.com \\ ${ }^{2}$ Program Studi Magister Ilmu Keperawatan, Fakultas Keperawatan, Universitas Hasanuddin \\ Email : kadek20_uh@yahoo.com \\ ${ }^{3}$ Fakultas Kedokteran, Universitas Hasanuddin \\ Email: wardihans@gmail.com
}

\begin{abstract}
Restless legs syndrome (RLS) is a common sensorimotor disorder in patients with chronic renal failure who undergo hemodialysis (HD). Pharmacological therapy is the main choice of RLS treatment that is at risk of side effects. Physical optimization of HD patients through stretching exercise is considered potentially effective in treating restless legs syndrome. This study aimed to identify the effect of stretching exercise on RLS in patients with chronic renal failure who underwent HD at Hasanuddin University Hospital. This research method used a quasi-experiment with pre- and post-test with control group design. The subjects in this study were 20 HD patients divided into two groups: 10 patients, Intervention and 10 control patients. Stretching exercise is given twice a week during the hemodialysis process, for 4 weeks. The RLS scale was measured using International Restless Leg Sydrome Scale (IRLS). The collected data were then analyzed using the Wilcoxon test. The results showed that the respondents who received stretching exercise intervention experienced a decreaseof the RLS scale more significantly than the control group with $\rho=0.001(\rho<0.05)$. This showed that there is a stretching exercise effect on the decrease of RLS scale. Therefore, stretching exercise could be made as one of the intervention treatment in which can be used to treat the patients with chronic renal failure and experienced RLS.
\end{abstract}

Keywords: Stretching exercise, Restless Legs Syndrome, RLS Scale.

\section{PENDAHULUAN}

Gagal ginjal kronik (GGK) atau chronic kidney disease $(\mathrm{CKD})$ merupakan penurunan fungsi ginjal yang bersifat irreversibel dan progresif yang ditunjukkan oleh laju filtrasi glomerulus (GFR) kurang dari $60 \mathrm{~mL} / \mathrm{menit}$ per $1,73 \mathrm{~m}^{2}$, yang terjadi selama 3 bulan atau lebih dengan etiologi yang beragam, sehingga mengakibatkan tubuh gagal untuk mempertahankan metabolisme dan keseimbangan cairan dan elektrolit sehingga menyebabkan terjadinya uremia. (Smeltzer \& Bare, 2009; Black \& Hawk, 2014; Webster et al, 2016; Hosseini, Kazemi \& Azimpar, 2016).

Insiden penyakit gagal ginjal kronik sangat beragam bergantung pada keadaan tiap negara dan dipastikan akan meningkat setiap tahunnya (Cheema et al, 2006; Black \&
Hawk, 2014; Gilman et al, 2017). Menurut United States Renal Data Service (USRDS) (2015) prevalensi gagal ginjal kronik disemua populasi mencapai angka $14 \%$ yang mana penyebab utamanya adalah hipertensi dan diabetes. Berdasarkan data The Global Burden of Disease tahun 2010, GGK menduduki peringkat ke-18 dalam daftar penyebab mortalitas dari sejumlah angka kematian global yaitu 16,3 per 100 ribu (Lazano, Naghavi, \& Foreman, 2012)

Di Amerika Serikat menurut laporan USRDS bahwa angka kejadian gagal ginjal kronik di tahun 2013 mencapai angka 117.162 dan terus meningkat mencapai 363 kasus baru persejuta orang tiap tahunnya, dan $88,2 \%$ diantaranya menjalani terapi pengganti ginjal dengan hemodialisis. Kondisi ini juga terjadi di Indonesia dengan angka penderita menurut 
data Indonesian Renal Registry (2015) sebanyak 29.182 orang yang tersebar di seluruh daerah di Indonesia, dengan terapi hemodialisis rutin mencapai $95 \%$ dari total seluruh tindakan (Indonesian Renal Registry, 2015).

Hilangnya fungsi ginjal membuat seseorang memerlukan terapi penggantian ginjal (renal replacement therapy) yang merupakan salah satu terapi yang dipertimbangkan pada pasien penyakit ginjal kronik tahap akhir untuk tetap bertahan hidup yaitu berupa dialisis, salah satu tindakan dialisis yaitu hemodialisis yang merupakan suatu metode artifisial untuk membuang limbah dari darah dengan mengeluarkannya dari tubuh melalui ginjal buatan dan memerlukan terapi dialisis jangka pendek atau terapi jangka panjang bahkan permanen (Le Mone \& Burke, 2008; Smeltzer \& Bare, 2009; Syamsuddin, 2011; Shahgholian Jazi, \& Karimian, 2015). Bagi penderita gagal ginjal kronis, hemodialisis akan memperpanjang usia harapan hidup. Namun demikian hemodialisis tidak menyembuhkan atau memulihkan penyakit ginjal. Pasien akan tetap mengalami sejumlah permasalahan dan komplikasi serta adanya berbagai perubahan pada bentuk dan fungsi sistem dalam tubuh (Smeltzer \& Bare, 2009; Parker, 2009).

Salah satu permasalahan yang sering dikeluhkan pasien gagal ginjak kronik adalah Restless leg syndrome (RLS) atau yang juga dikenal dengan istilah Willis-Ekbom Disease (WED) (Shahgholian et al, 2015; Kligelhoefer, Bhattacharya, \& Reichman, 2016). RLS merupakan gangguan neurologis sensorik-motorik umum yang ditandai dengan kegelisahan intens dan sensasi yang tidak nyaman pada anggota gerak bagian bawah seperti nyeri dan kesemutan, gejala muncul ketika dalam kondisi beristirahat dan kondisi terburuk biasanya terjadi di malam hari. sehingga memaksa pasien untuk terus menggerakkan kaki bahkan sampai dengan berjalan-jalan agar merasa nyaman dan tentu saja hal tersebut mengarah ke kualitas hidup pasien dan mempengaruhi fungsi tubuh. Sindrom ini lebih lazim terjadi pada pasien gagal ginjal kronis dibandingkan dengan populasi lainnya, prevalensi di antara pasien hemodialisis menunjukkan 20-80\% dan beberapa penelitian juga menunjukkan bahwa $33 \%$ pasien End Stage Renal Disease (ESRD) mengalami RLS. (Lin, 2016; Shahgholian et al, 2015; Aliasghapour, Abbasi, \& Razi., 2016; Ekbom \& Ulfberg, 2009)

Patofisiologi RLS belum diketahui secara pasti namun dikatakan bahwa sistem dopaminergik berperan penting dalam menyebabkan sindrom tersebut. Dibeberapa penelitian menunjukkan beberapa cara yang dapat dilakukan untuk mengatasi RLS baik secara farmakologi, non farmakologi, maupun perawatan intensive khusus termasuk perawatan komplementer (Shahgholian et al, 2015; Klingelhoefer et al, 2016). Salah satu tindakan yang direkomendasikan untuk mengatasi RLS pada pasien dengan GGK dapat dilakukan dengan teknik non farmakologi termasuk latihan fisik setiap hari seperti stretching exercise, mengingat jumlah obat yang dikonsumsi pasien dengan GGK sudah cukup tinggi, dan sebagian besar obatobat diekskresikan melalui ginjal, tentu saja hal ini akan berdampak buruk pada kondisi pasien apabila diberikan obat lain untuk pengobatan RLS, oleh karena hal tersebut metode non farmakologi sepeti streching Exercise akan sangat membantu pasien dalam mengatasi RLS (Aliasghapour et al, 2015; Hosseini et al ,2016; Shahgholian et al, 2015). Streching exercise merupakan salah satu metode pengobatan tertua diantara metode terapi gerak dan memiliki efek yang positif pada beberapa tanda-tanda sindrom (Mostmand et al, 2010). Selama dialisis program stretching exercise dapat dilakukan pada pasien dengan didukung fasilitas dan dimonitor oleh perawat. Stretching exercise yang dilakukan selama dialisis dapat meningkatkan sirkulasi pada otot, memfasilitasi penyediaan nutrisi ke sel dan memperbesar luas permukaan kapiler sehingga meningkatkan perpindahan urea dan toksin dari jaringan ke vaskuler dan mengurangi manifestasi dari RLS (Parson \& Tosseimire, 2006; Shahgholian et al, 2015).

Berdasarkan penelitian yang dilakukan Ouzouni et al (2009) dikatakan bahwa latihan 
fisik selama hemodialisis dapat meningkatkan VO2 peak, menurunkan self - reported depression, serta menunjukkan perkembangan yang signifikan pada quality of life index dan life satisfaction index. Latihan fisik selama hemodialisis dapat menjaga stabilitas tekanan darah sistolik dan diastolik (Hidayati, 2009). Selain itu Aliasghapour et al (2015) dan Kaur, Venkateasan, \& Kaur (2016) dalam penelitiannya juga mengemukakan bahwa latihan fisik dengan stretching exercise selama hemodialisis yang dilakukan secara teratur dapat mengatasi RLS dengan nilai signifikansi $\mathrm{p}<0,001$.

Berdasarkan fakta tersebut sebagai seorang perawat hemodialisis tentunya mempunyai peranan penting dalam perawatan pasien yang menjalani hemodialisis. Peran perawat sebagaimana yang diketahui adalah sebagai care provider, pendidik, konsultan, administrator dan peneliti yang sebagian besar kegiatan perawat hemodialisis dilakukan dengan tidak adanya dokter, sehingga peran mereka dalam pengobatan pasien diperkirakan mencapai 80\% (Hashemi, 2013). Selain itu, perawat memiliki tugas dalam mendorong keberkelanjutan latihan fisik yang menjadi dasar pasien dalam melakukan aktifitas fisik (Bennett et al. , 2013). Namun pelaksanaan program latihan di unit hemodialisis di Indonesia belum diterapkan. Program latihan fisik belum menjadi program protokol rutin bagi pasien hemodialisis di Indonesia. Stretching sebagai salah satu jenis latihan fisik dalam penelitian sebelumnya berpengaruh positif bagi pasien hemodialisis dan merupakan salah satu bentuk intervensi keperawatan yang terdapat dalam standar Nursing Intervention Classification (2014) untuk meningkatkan aktivitas fisik pasien hemodialisis, namun belum diketahui pengaruh latihan kekuatan tersebut terhadap pasien hemodialisis yang mengalami RLS.

Penelitian tentang pengaruh Stretching exercise selama hemodialisis terhadap skala restless leg syndrom belum pernah dilakukan di Rumah Sakit Universitas Hasanuddin, sehingga penulis bermaksud untuk melakukan penelitian untuk mengetahui efek Stretching exercise yang dilakukan selama hemodialisis terhadap skala restless leg syndrom pada pasien dengan gagal ginjal kronik sehingga dapat dijadikan sebagai suatu intervensi dalam memberikan asuhan keperawatan secara komprehensif.

\section{METODE}

Penelitian ini dilakukan di unit hemodialisis RS. Universitas Hasanuddin dengan menggunakan desain penelitian Quasi eksperimental, dengan rancangan nonequivalent control group dengan Pre-Post test design. Penelitian ini dilaksanakan selama empat minggu yaitu dimulai dari bulan oktober sampai dengan November 2017.

Sampel yang berpartisispasi dalam penelitian ini sebanyak 20 responden yang dibagi menjadi dua kelompok yaitu 10 responden kelompok intervensi dan 10 kelompok kontrol dengan menggunakan teknik purposive sampling yang telah memenuhi kriteria, antara lain: Pasien gagal ginjal kronik yang menjalani hemodialisa rutin dua kali seminggu dan memiliki kriteria RLS, tidak mengalami komplikasi hemodialisis (hipotensi, kram, sakit kepala/pusing), tidak mengalami fraktur dan tidak terpasang akses femoral.

Pengukuran skala RLS menggunakan International Restless Leg Syndrom (IRLS). International Restless Legs Scale berupa kuisioner dan skala ordinal yang terdiri dari 10 pertanyaan yang mencakup gejala dan efek terhadap perasaan dan kehidupan pasien. Setiap pertanyaan terdiri dari 5 poin. Skala yang terdapat pada IRLS terbagi menjadi 4 interval, yaitu sangat parah (31-40 poin), parah (21-30 poin), sedang (11-20), cukup (1-10 poin), tidak parah (0 poin) dan untuk skala ordinal yang digunakan terbagi menjadi sangat parah (7-8), parah (5-6), cukup (3-4), sedikit parah (1-2) (IRLSSG, 2003).

Stretching Exercise diberikan secara individual. Gerakan terdiri dari peregangan pada bagian paha bagian belakang, gluteal, paha bagian luar dan dalam, serta peregangan pada bagian betis dan kaki. Peneliti memberikan terapi Stretching Exercise sebayak dua kali dalam seminggu, selama 20 menit untuk setiap sesi yang dilakukan, 
penelitian ini dilakukan selama empat minggu. Sebelum pemberian Stretching Exercise responden di ukur skala RLSnya kemudian di ukur kembali setelah pemberian terapi.

Data yang diperoleh selanjutnya dianalisis dengan menggunakan program SPSS for windows dengan menggunakan uji parametrik. Sebelumnya, dilakukan uji normalitas data dengan menggunakan uji Kolmogorov Smirnov. selanjutnya dianalisis dengan menggunakan uji statistik Wilcoxon dan Friedman dengan tingkat kemaknaan/ kesalahan 5\% $(0,05)$.

\section{HASIL DAN PEMBAHASAN}

Berdasarkan karekteristik umur dari 20 responden yang dibagi menjadi dua kelompok, menunjukkan bahwa rata-rata usia responden dengan standar deviasi yang dirawat di ruang hemodialisa RS.Universitas Hasanuddin pada kelompok intervensi adalah $47.80 \pm 12.68$ tahun, usia minimum responden adalah 25 tahun dan usia maksimum 62 tahun sedangkan pada kelompok kontrol rata-rata usia responden $46.40 \pm 15.02$ tahun, usia minimum responden 22 tahun dan usia maksimum 64 tahun. Berdasarkan lama HD rata-rata responden pada kelompok intervensi adalah $2.50 \pm 0.70$ tahun. lama HD responden yang paling singkat adalah satu tahun sedangkan waktu yang terlama adalah tiga tahun. Sementara pada kelompok kontrol ratarata lama HD responden $2.00 \pm 0.81$ tahun, lama HD minimum responden adalah satu tahun dan maksimum tiga tahun, sedangkan pada nilai rata-rata skala RLS responden pada kelompok intervensi dan kelompok kontrol masing-masing adalah $5.60 \pm 0.97$ dan 5.30 \pm 0.94 , nilai RLS minimum dan maksimum pada kedua kelompok memiliki nilai yang yang sama yaitu berada pada nilai 4.00 sampai dengan 7.00.

Berdasarkan karekteristik jenis kelamin, diketahui bahwa jenis kelamin responden pada kelompok intervensi sebagian besar berjenis kelamin laki laki (80\%) sedangkan pada kelompok kontrol memiliki perbandingan yang sama yaitu 50\% laki-laki dan perempuan. Begitupula dengan tingkat pendidikan kelompok intervensi memiliki jumlah yang sama antara tingkat pendidikan SMA dan Perguruan tinggi yaitu sebesar 50\%, sedangkan pada kelompok kontrol tingkat pendidikan responden sebagian besar memiliki tingkat pendidikan SMA (60\%). Untuk pekerjaan baik pada kelompok intervensi $(60 \%)$ maupun kelompok kontrol $(70 \%)$ sebagian besar responden tidak bekerja. Perbedaan skala RLS sebelum dan setelah diberikan stretching exercise pada kelompok intervensi dan kelompok kontrol dapat dilihat pada Gambar 1. Perbedaan selisih skala RLS setelah pemberian stretching exercise pada kelompok intervensi dan kelompok control dapat dilihat pada Gambar 2. dan; Perbedaan skala RLS setelah delapan kali pemberian stretching exercise pada kelompok intervensi dan kelompok kontrol dapat dilihat pada Tabel 3.

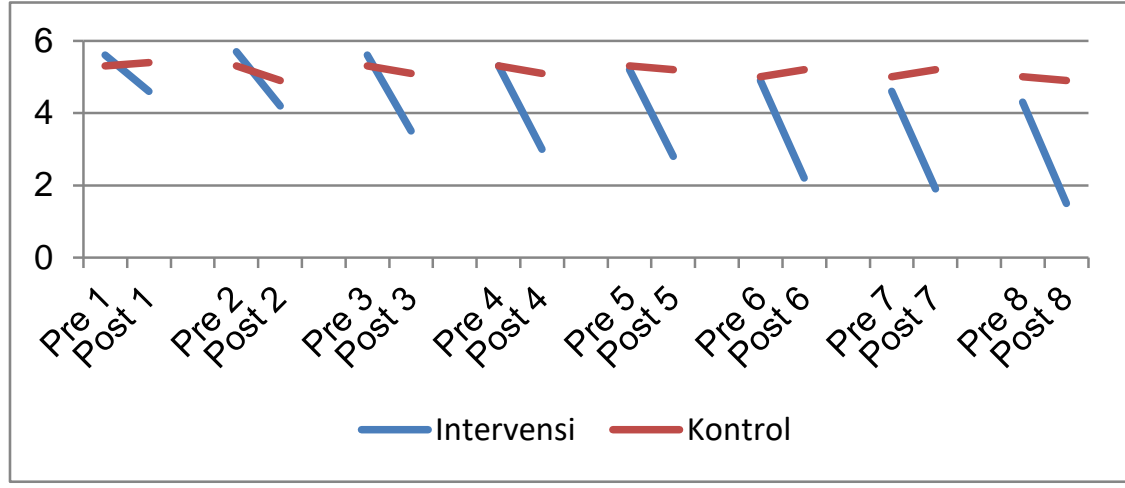

Gambar 1. Grafik rata-rata skala RLS sebelum dan setelah diberikan stretching exercise pada kelompok intervensi dan kelompok kontrol $(n=20)$ 


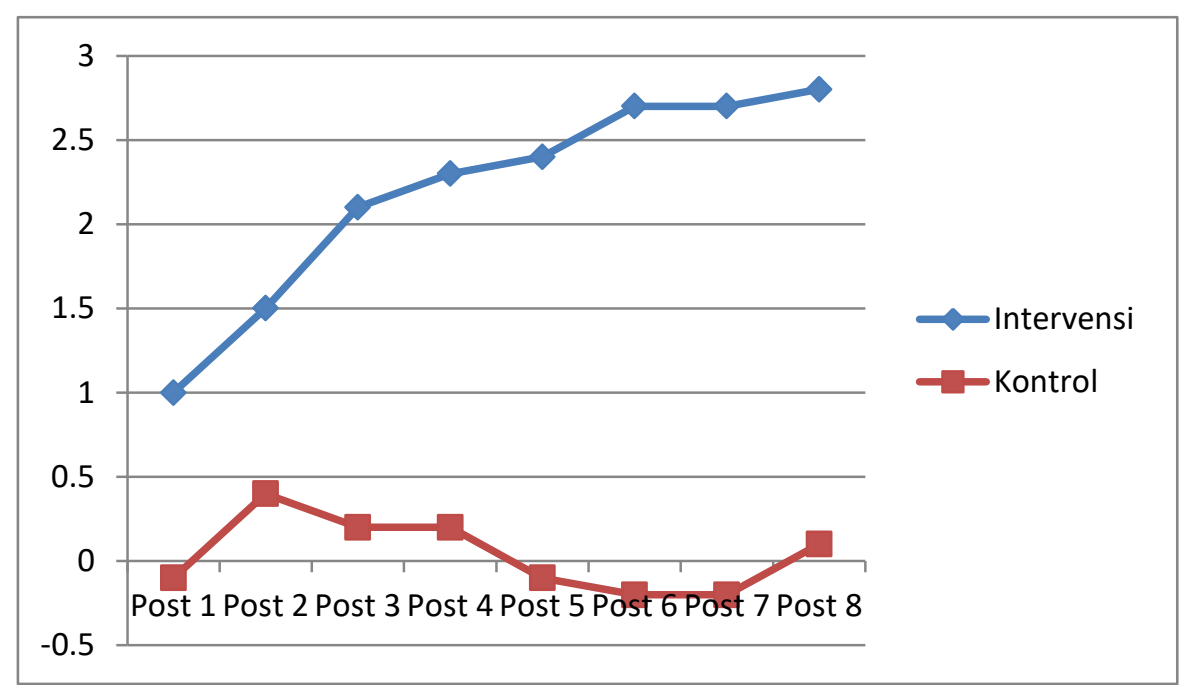

Gambar 2. Grafik rata-rata selisih skala RLS setelah pemberian stretching exercise pada kelompok intervensi dan kelompok kontrol

Tabel 3. Perbedaan skala RLS setelah delapan kali pemberian stretching exercise pada kelompok intervensi dan kelompok kontrol $(\mathrm{n}=20)$

\begin{tabular}{lcccccccccc}
\hline Skala RLS & $\begin{array}{c}\text { Pre } \\
\text { mean } \pm \text { SD }\end{array}$ & $\begin{array}{c}\text { Post }-1 \\
\text { mean } \pm \text { SD }\end{array}$ & $\begin{array}{c}\text { Post }-2 \\
\text { mean } \pm \text { SD }\end{array}$ & $\begin{array}{c}\text { Post }-3 \\
\text { mean } \pm \text { SD }\end{array}$ & $\begin{array}{c}\text { Post }-4 \\
\text { mean } \pm \text { SD }\end{array}$ & $\begin{array}{c}\text { Post }-5 \\
\text { mean } \pm S D\end{array}$ & $\begin{array}{c}\text { Post }-6 \\
\text { mean } \pm \text { SD }\end{array}$ & $\begin{array}{c}\text { Post }-7 \\
\text { mean } \pm S D\end{array}$ & $\begin{array}{c}\text { Post }-8 \\
\text { mean } \pm S D\end{array}$ & $p$ \\
\hline Kelompok & $5.60 \pm$ & $4.60 \pm$ & $4.20 \pm$ & $3.50 \pm$ & $5.10 \pm$ & $3.00 \pm$ & $5.10 \pm$ & $3.00 \pm$ & $5.20 \pm$ & $<0.001$ \\
$\begin{array}{l}\text { Intervensi } \\
(\mathrm{n}=10)\end{array}$ & 0.933 & 0.699 & 0.789 & 0.850 & 0.876 & 0.816 & 0.876 & 0.632 & 1.135 & \\
\hline $\begin{array}{l}\text { Kelompok } \\
\text { kontrol } \\
(\mathrm{n}=10)\end{array}$ & $5.30 \pm$ & $5.40 \pm$ & $4.90 \pm$ & $2.20 \pm$ & $5.20 \pm$ & $1.90 \pm$ & $5.20 \pm$ & $1.50 \pm$ & $4.90 \pm$ & 0.282 \\
\hline
\end{tabular}

Berdasarkan hasil penelitian yang telah dilakukan, menunjukkan bahwa terdapat perbedaan yang bermakna secara statistik pada skala RLS pada kelompok intervensi dan kontrol $(\mathrm{p}=<0,001)$. Stretching exercise yang diberikan pada kelompok intervensi selama empat minggu, menunjukkan adanya perbaikan kondisi RLS pada kelompok intervensi sedangkan pada kelompok kontrol menggambarkan tidak adanya perbaikan kondisi ataupun penurunan skala RLS yang dialami. Hal ini menunjukkan terdapat penurunan skala RLS setelah stretching exercise pada kelompok intervensi. Temuan ini sejalan dengan penelitian sebelumnya. Hasil dalam penelitian ini didukung oleh penelitian yang dilakukan oleh Kaur et al, (2016); Aliasgharpour et al (2016); dan Christoforos, Georgeus \&
Loannis. (2010), meskipun terdapat perbedaan dengan penelitian sebelumnya, perbedaan penelitian tersebut dengan penelitian ini terdapat pada bagian tubuh yang dilakukan stretching dan durasi waktu pemberiannya. Latihan fisik yang diberikan berupa stretching exercise ternyata terbukti efektif mengurangi gejala RLS pada pasien gagal ginjal kronik yang menjalani hemodialisis dengan nilai signifikansi $\mathrm{p}=<0.001$.

Perbaikan kondisi RLS pada kelompok intervensi dalam penelitian ini diperkuat dengan penjelasan bahwa aktivitas fisik berupa stretching exercise merupakan stimulus adaptasi fungsional dan metabolik pada neuromuskular. Stretching exercise memberikan hasil pada penguatan otot rangka dan peningkatan kekuatan secara 
maksimal. Latihan berupa Stretching exercise juga telah terbukti memengaruhi fungsi kontrol motor dan peningkatan aliran darah ke otak (Graef, Michaelsen, \& Pereira, 2014). Stretching exercise dipercaya dapat menyeimbangkan produksi dopamin dan hormon endorphin (Seifer, Brassard, \& Stallknecht, 2010). Dopamine dikenal sebagai neurotransmitter yang menghantarkan sinyal di dalam otak dan diketahui memiliki fungsi bagi organ-organ lain. Di susunan saraf pusat, dopamine memiliki peran dalam mengatur pergerakan, pembelajaran, daya ingat, emosi, rasa senang, tidur, dan kognisi, sedangkan hormon endorphin sendiri merupakan neuropeptide yang dihasilkan oleh tubuh ketika keadaan rileks (Harry, 2006; Sherwood, 2014). Hormon endorphin bertindak langsung sebagai hormon yang menenangkan yang diproduksi oleh otak dan menghasilkan rasa nyaman dan meningkatkan kadar endorphin dalam tubuh untuk mengurangi rasa nyeri pada saat kontraksi ketika melakukan stretching, terbukti kadar beta-endorphine dapat meningkat hingga 4-5 kali di dalam darah. Ketika seseorang melakukan olahraga dalam bentuk stretching, maka beta-endorphine akan ditangkap oleh reseptor di dalam hipotalamus dan sistem limbik yang berfungsi untuk mengatur emosi. Ketika neuron perifer mengirikan sinyal ke sinaps, yang terjadi adalah sinapsis antara neuron nyeri perifer dan neuron yang menuju otak tempat seharusnya substansi $\mathrm{P}$ akan menghantarkan impuls. Pada saat yang bersamaan endorphin akan memblokir lepas nya substansi P dari neuron sensorik, sehingga transmisi impuls nyeri di medulla spinalis menjadi terhambat, maka tingkat ketidaknyamanan berkurang. Peningkatan beta-endorphin diketahui dapat meningkatkan nafsu makan, peningkatan daya ingat, memperbaiki nafsu makan dan penurunan nyeri sehingga olahraga dalam bentuk stretching efektif dalam menurunkan tingkat nyeri terutama Ketidaknyamanan pada RLS (Harry, 2006).

Pada pasien RLS memiliki karakteristik difisit dopamin yang menyebabkan gangguan motorik sehingga melalui keterampilan motorik berupa skill exercise akan membantu dalam melakukan kontrol motor. Mayoritas responden di kedua kelompok pada penelitian ini menunjukkan rentang skala kondisi RLS yang sedang sampai parah. Hal tersebut dapat ditunjukan dengan nilai mean 5.60 pada kelompok intervensi dan 5.30 pada kelompok kontrol.

Gerakan latihan kekuatan yang diberikan dalam penelitian ini merujuk pada penelitian yang dilakukan oleh Aliasgharpour et al (2016) dan Shahgholian et al (2016) yaitu berupa latihan peregangan yang bisa sangat membantu pasien, karena gerakan yang dilakukan hanya fokus pada tungkai tubuh bagian bawah dan tidak memiliki efek samping saat dilakukan hemodialisis. Gerakan dalam latihan kekuatan yang diberikan dalam penelitian Aliasgharpour et al (2016), terdiri dari enam gerakan yang dilakukan pada ekstremitas bawah, dimana gerakan tersebut juga terdapat dalam prosedur latihan pasien hemodialisis Painter (2000) dan Mahrova \& Svagrova (2013).

Selama responden diberikan intervensi, tidak terdapat responden yang mengalami proses pemberhentian hemodialisis, namun satu responden mengalami kram kaki ringan. Hal tersebut terjadi disebabkan oleh peningkatan QB pada mesin hemodialisis yang dinaikkan. Pemantauan tanda-tanda vital selalu dilakukan peneliti sebelum diberikan dan selalu termonitor selama melakukan intervensi, hal ini ditujukan untuk memastikan keamanan latihan yang diberikan terhadap kondisi pasien begitupun setelah perlakuan kembali diobservasi oleh peneliti. Berdasarkan studi literatur bahwa dengan melakukan gerakan ringan berupa stretching exercise berpotensi memperbaiki kondisi RLS karena dengan peningkatan perengangan otot akan berpengaruh terhadap kestabilan kontrol motor (Griffin \& Cafarelli, 2005). Sehingga berdasarkan hasil penelitian tersebut, peneliti mengambil gerakan minimal dalam prosedur latihan namun tetap memberikan pengaruh terhadap RLS dalam penelitian ini. 
Durasi atau lamanya pemberian intervensi, menentukan keoptimalan dari latihan kekuatan yang diberikan. Lamanya waktu sesi gerakan dan durasi penelitian ini mengacu pada penelitian yang dilakukan oleh Aliasgharpour et al (2016). Stretching exercise dalam penelitian ini diberikan selama empat minggu, sesuai dengan review penelitian-penelitian sebelumnya yang telah dilakukan. Pemilihan waktu selama empat minggu sesuai dengan penelitian yang dilakukan oleh Kaur et al (2016) dan Aliasgharpour et al (2016) yang menunjukkan perbaikan skala RLS pasien setelah empat minggu pemberian intervensi.

Penelitian lain melaporkan penurunan skala RLS setelah pemberian perlakuan dengan durasi waktu yang lebih lama yaitu 16 minggu yang dilakukan oleh Sakkas et al. (2008), enam bulan oleh Mortazavi et al. (2013), dan Giannaki et al. (2013). Sehingga berdasarkan keefektifan waktu exercise tersebut, peneliti memilih waktu selama empat minggu untuk dilakukan dalam penelitian ini.

Smart \& Stelee (2013) melakukan review lama pemberian latihan fisik bagi pasien gagal ginjal kronis yaitu tiga kali dalam seminggu. Frekuensi hemodialisis yang diberikan di Indonesia umumnya dilakukan dua kali seminggu. Smart dan Stelee (2013) merekomendasikan latihan fisik dalam jangka waktu lama yaitu lima bulan sehingga dapat memberikan efek yang menguntungkan. Morishita \& Nagata (2015) melakukan review dosis latihan fisik pada penyakit gagal ginjal kronis, akan didapatkan efek positif pada pasien yang menjalani hemodialisis jika melakukan latihan fisik selama 2-3 kali dalam seminggu, hal yang sama juga dikemukakan oleh National Kidney Foundation Kidney Disease Outcome Quality Initiative (2005) dan Cocharane Collaboration Guidelines (2011) merekomendasikan untuk melakukan latihan fisik selama 30 menit, tiga kali dalam seminggu. Sebaliknya, beberapa peneliti seperti Ohayon \& Roth (2002) menunjukkan bahwa aktivitas fisik yang cukup seperti olahraga dengan intensitas tinggi sebelum waktu tidur berhubungan dengan skala RLS. Oleh karena itu, pasien hemodialisis dianjurkan untuk menghindari program olahraga berat terutama sebelum tidur. Perbedaan rentang waktu dan dosis latihan fisik yang diberikan memengaruhi hasil dalam penelitian ini. Namun, dalam penelitian ini menunjukkan perbaikan pada kelompok intervensi selama empat minggu perlakuan.

\section{KESIMPULAN}

Berdasarkan dari hasil penelitian yang dilakukan dapat disimpulkan bahwa secara statistik terdapat perbedaan skala RLS sebelum dan setelah delapan kali pemberian stretching exercise pada kelompok intervensi. dibandingkan kelompok kontrol, hal ini menunjukan bahwa secara klinis terdapat perbaikan RLS di kelompok intervensi setelah diberikan stretching exercise. Sedangkan skala RLS post test di kelompok kontrol terlihat tidak ada perubahan secara signifikan. Hal tersebut menyimpukan bahwa latihan kekuatan memberikan pengaruh terhadap perbaikan kondisi RLS pada pasien gagal ginjal kronik yang mengalami RLS.

\section{REFERENSI}

1. Aliasgharpour, M., Abbasi, Z., Razi, S.P \& Kazemnezhad, A. 2016. The effect of stretching exercises on severity of restless legs syndrome in patients on hemodialysis. Asian J Sports Med. 7 (2). doi: 10.5812/asjsm.31001.

2. Australia and New Zealand Dialysis and Transplant Registry. 2015. The 38th annual ANZDATA report. Retrived from http://www.anzdata.org.au/v1/report 201 5.html.

3. Black, J. M \& Hawks, J. H. 2014. Keperawatan medikal bedah. Edisi 8. Buku 2. Singapore: Elsevier.

4. Cheema, B. S., O’Sullivan. J, Chan, M., Patwardhan A., Kelly, J., Gillin, A., Fiatarone S.M.A. 2006. Progressive resistance training during hemodialysis : rationale and method of a randomized- 
controlled trial. Hemodialysis International Journal. doi: 10.1111/j.1542-4758.2006.00112.x.

5. Christoforos, D.G., Georgios, M.H., Christina, K., Maria, D.M., Yiannis K., Paraskevi, F., ..., Ioannis, S. 2010. A single-blind randomized controlled trial to evaluate the effect of 6 months of progressive aerobic exercise training in patients with uraemic restless legs syndrome. ASAIO Journal, 56, 538-542. DOI: $10.1097 /$ MAT.0b013e3181f1cc04

6. Ekbom, K., \& Ulfberg, J. 2009. Restless legs syndrome. Journal of Internal Medicine, 266; 419-431. doi: 10.1111/j.1365-2796.2009.02159.x

7. Giannaki, C.D., Sakkas, G.K., Hadjigeorgiou, G.M., Karatzaferi, K., Patramani, G., \& Lavdas, E. 2010. Non-pharmacological management of periodic limb movements during hemodialysis session in patients with uremic restless legs syndrome. ASAIO Journal, 56, 538-542

8. Gilman, E.A., Feely, M.A., Hildebrandt, D., Varayil, J.E., Chong, E.Y., Williams, A.W., Mueller, P.S. 2017. Do patients receiving hemodialysis regret starting dialysis? A survey of affected patients. Clinical Nephrology, Vol 87,117-123. doi 10.5414/CN109030.

9. Graef, P., Michaelsen, S.M., Dadalt, M.L.R., Rodrigues, D.A.M.S., \& Pereira, F. 2014. Effects of functional and analytical strength training on upperextremity activity after stroke: A randomized controlled trial. Braz J Phys Ther, 1-3

10. Griffin,L., Cafarelli, E. 2005. Resistence training: cortical, spinal and motor unit adaptation. Can.J.Appl.Phsiol. 30(3):328-340

11. Heiwe, S., Jacobson S.H. 2011. Exercise training for adults with chronic kidney disease. Cochrane Database Syst Rev;10:CD003236

12. Hidayati, W. 2009. Laporan analisis praktek residensi spesialis keperawatan medikal bedah peminatan sistem perkemihan di RSUPN Dr. Cipto
Mangunkusumo dan RS PGI Cikini, tidak dipublikasikan.

13. Hosseini, H., Kazemi, M., Azimpour. 2016. The effect of vibration on the severity of restless legs syndrome in hemodialysis patients. Journal of Renal Injury Prevention. 6(2): 113-116. doi: 10.15171/jrip.2017.22.

14. Indonesian Renal Registry. 2015. 8th report of Indonesian renal registry. Retrived from. http://www.indonesianrenalregistry.org/d ata/INDONESIAN\%20RENAL\%20REG ISTRY\%202015.pdf

15. K/DOQI Workgroup. 2005. K/DOQI clinical practice guidelines for cardiovascular disease in dialysis patients. Am J Kidney Dis.;45: S1-S153.

16. Kaur , J., Venkateasan, M., Kaur, K., Rawat, P.S., Massey, H. 2016. Effectiveness of muscle stretching exercise on quality of life of haemodialysis patients. International Journal of Medical Research \& Health Sciences, 5, 4:203-207. ISSN No: 23195886

17. Klingelhoefer, L., Bhattacharya, K., Reichmann, H., 2016. Restless legs syndrome. Clin Med. 16:379-82. doi: 10.7861/ clinmedicine.16-4-379.

18. Lazano, R., Naghavi, M., Foreman, K., Lim, S., Shibuya, K., Aboyans, ..., Adair, I. 2012. Global and regional mortality from 235 causes of death for 20 age groups in 1990 and 2010: A systematic analysis for the Global Burden.

19. Mahrova A., Svagrova K. 2013. Exercise Therapy-Additional Tool for Managing Physical and Psychological Problems on Hemodialysis. In: Suzuki H, editor. Hemodialysis. InTech.

20. Morishita, Y., Nagata, D. 2015. Strategies to improve physical activity by exercise training in patiens with chonic kidney disease. International Journal of Neprology And Renovascular Disease. 8:19-24.

21. Mortazavi, M.,Vahdatpour, B.,Ghasempour, A.,Taheri, D., Shahidi, S., \& Moeinzadeh, F. 2013. Aerobic 
exercise improves signs of restless leg syndrome in end stage renal disease patients suffering chronic hemodialysis. The Scientific World Journal,1-4.

22. National Kidney Foundation. 2015. KDOQI clinical practice guideline for hemodialysis adequacy: 2015 update. $\mathrm{Am}$ J Kidney. 66(5):884-930.

23. ----.-. 2012. KDOQI clinical practice guideline for diabetes and CKD: 2012 update. Am J Kidney. 60(5):850886.

24. LeMone, P., Burke, K. 2008. Medical surgical nursing critical thinking in care. New Jearsey : Pearson.

25. Lin Z., Zhao,C., Luo, Q., Xia, X., Yu, X., \& Huang, F. 2016. Prevalence of restless legs syndrome in chronic kidney disease: a systematic review and meta analysis of observational studies. Renal Failure J. http://dx.doi.org/10.1080/0886022X.201 6.1227564.

26. Ohayon MM, Roth T. 2002. Prevalence of restless legs syndrome and periodic limb movement disorder in the general population. J Psychosom Res. 53(1):54754.

27. Painter, P. 2000. A guide for people on dialysis. Rehabilitation Resource Center: Medical Education Institute, Inc.

28. Parsons, T.K., Tosselmire E.D., KingVanVlack, C.E. 2006. Exercise training during hemodialysis improves dyalisis efficacy and physical performance. Exercise Arch phys med rehabil, 87(5):680-7.doi 10.1016/j.apmr.2005.12.044.

29. Sakkas GK, Hadjigeorgiou GM, Karatzaferi C, Maridaki MD, Giannaki CD, Mertens PR. (2008) .Intradialytic aerobic exercise training ameliorates symptoms of restless legs syndrome and improves functional capacity in patients on hemodialysis: a pilot study. ASAIO J
54(2):185-90.

doi: 10.1097/MAT.0b013e3181641b07.

30. Seifer, T., Brassard, P., Wissenberg, M., Rasmussen, P., Nordby, P., Stallknecht, B., ..., Secher, N.H. 2010. Endurance training enhances BDNF release from the human brain. Am J Physiol Regul Integr Comp Physiol, 298, R372-R377.

31. Shahgholian, N., Ghafourifard, M., Rafieian,M., \& Mortazavi, M. 2008. Impact of two types of sodium and ultrafiltration profiles on intradialytic hypotension in hemodialysis patients. IJNMR Autumn. 13, 135-136.

32. Shahgholian, N., Jazi, S.K., Karimian, J., Valiani, M. 2015. The effects of two methods of reflexology and stretching exercises on the severity of restless leg syndrome among hemodialysis patients. Iranian Journal of Nursing and Midwifery Research, 21:219-24. doi : 10.4103/1735-9066.180381.

33. Sherwood, L. 2014. Fisiologi manusia : dari sel ke sistem. Edisi 8. Jakarta: EGC

34. Smart, N., \& Stelee, M. 2011. Exercise training in haemodialysis patients: A systematic review and meta-analysis. Nephrology, 16, 626632. doi:10.1111/j.14401797.2011.01471.x

35. Smeltzer, S.C., \& Bare. B.G. 2009. Buku ajar keperawatan medikal bedah brunner \&. suddarth ( Edisi 8 Volume 1). Philladelphia: Lipincott Williams \& Wilknis.

36. United State Renal Data System. 2015. USRDS annual data report volume 2: ESRD in the United States. Retrived from

https://www.usrds.org/2015/download/vo 12 USRDS ESRD 15.pdf 